\title{
Fenoldopam to prevent acute kidney injury after major surgery-a systematic review and meta-analysis
}

\author{
Michael A. Gillies ${ }^{1}$, Vivek Kakar ${ }^{2}$, Robert J. Parker ${ }^{3}$, Patrick M. Honoré ${ }^{4}$ and Marlies Ostermann ${ }^{5^{*}}$
}

\begin{abstract}
Background: Acute kidney injury (AKI) after surgery is associated with increased mortality and healthcare costs. Fenoldopam is a selective dopamine-1 receptor agonist with renoprotective properties. We conducted a systematic review and meta-analysis of randomised controlled trials comparing fenoldopam with placebo to prevent AKI after major surgery.

Methods: We searched EMBASE, PubMed, meta-Register of randomised controlled trials and Cochrane CENTRAL databases for trials comparing fenoldopam with placebo in patients undergoing major surgery. The primary outcome was incidence of new AKI. Secondary outcomes were requirement for renal replacement therapy and hospital mortality.
\end{abstract}

Results: Eighty-three publications were screened; 23 studies underwent full data extraction and scoring. Six trials were suitable for inclusion in the data synthesis (total of 507 subjects undergoing cardiovascular surgery, partial nephrectomy, liver transplant surgery). Five studies were rated at high risk of bias. Data on post-operative incidence of AKI were available in five of the six trials (total of 471 patients) but definitions of AKI varied between studies. Of the 238 patients receiving fenoldopam, 45 (18.9\%) developed AKI compared to 62 (26.6\%) of the 233 patients who received placebo $\left(p=0.004, l^{2}=0 \%\right.$; random-effects model odds ratio $0.46,95 \%$ confidence interval 0.27-0.79). In patients treated with fenoldopam, there was no difference in renal replacement therapy $\left(n=478 ; p=0.11, P^{2}=47 \%\right.$; fixed-effect model odds ratio $0.27,95 \%$ confidence interval $0.06-1.19$ ) or hospital mortality ( $p=0.60, P^{2}=0 \%$; fixed-effect model odds ratio $1.0,95 \%$ confidence interval $0.14-7.37$ ).

Conclusions: In this analysis, peri-operative treatment with fenoldopam was associated with a significant reduction in post-operative AKI but it had no impact on renal replacement therapy or hospital mortality. Equipoise remains for further large trials in this area since the studies were conducted in three types of surgery, the majority of studies were rated at high risk of bias and the criteria for AKI varied between trials.

Keywords: Fenoldopam, AKI, Systematic review, Meta-analysis, Acute kidney injury

\section{Background}

Acute kidney injury (AKI) is an important complication of high-risk surgery and is associated with increased morbidity, mortality and healthcare costs [1-3]. Current management strategies are largely preventative and consist of avoidance of nephrotoxins, optimisation of haemodynamics (including arterial pressure) and correction

\footnotetext{
* Correspondence: Marlies.Ostermann@gstt.nhs.uk

${ }^{5}$ Department of Nephrology \& Critical Care Medicine, King's College London,

Guy's \& St Thomas' Foundation Hospital, London, UK

Full list of author information is available at the end of the article
}

of volume depletion. At present there are no therapeutic agents that have demonstrated efficacy in preventing or treating post-operative AKI.

Fenoldopam is a short-acting dopamine-1 receptor agonist, licensed for the treatment of hypertension. It decreases systemic vascular resistance while simultaneously increasing renal blood flow in patients with normal renal function and those with chronic kidney disease (CKD) [4]. It has been investigated in off-label studies as a potential agent to protect renal function during the peri-operative period $[5,6]$. In contrast to 
dopamine, it has no $\alpha$ - or $\beta$-receptor activity. Data from experimental AKI models suggest that it also has anti-inflammatory effects independent of its vasodilatory action [7].

At least three meta-analyses have suggested that fenoldopam may reduce the incidence of AKI, reduce the requirement for renal replacement therapy (RRT), and reduce mortality during critical illness and in patients undergoing cardiovascular interventions [8-10]. However, some of the studies included in these reviews were either non-randomised, studies with an active comparator, or trials performed in non-surgical patients.

Guidance on the role of fenoldopam in surgical and critically ill patients is conflicting. In 2010, the European Society of Intensive Care Medicine Working Group for Nephrology published recommendations for the prevention of AKI and suggested that the prophylactic use of fenoldopam should be considered in patients at high risk of AKI undergoing cardiovascular surgery [11]. Two years later, the Kidney Disease Improving Global Outcomes (KDIGO) expert committee released a new guideline and advised against the use of fenoldopam to prevent or treat AKI in any context [12]. New data produced in 2010-2012 may have contributed to the change in guidance.

Our aim was to review the existing data for fenoldopam as a renoprotective agent in the peri-operative setting and to perform a meta-analysis and systematic review of all existing randomised controlled trials (RCTs) comparing fenoldopam versus placebo in adult patients undergoing any type of major surgery.

\section{Methods}

\section{Search strategy}

We searched EMBASE, PubMed, meta-Register of RCTs (mRCT) and Cochrane CENTRAL databases using the following pre-agreed search strategy: (fenoldopam OR Corlopam) [tiab] AND rand*[tiab]. The search was limited to RCTs in adult subjects. The bibliographies of evaluable studies and other selected papers were hand searched. Authors of published studies were also contacted for more data as needed. Experts were contacted and asked if they were aware of other studies not identified by our search strategy. Two authors (VK and RJP) performed the literature search independently. Any disparities were resolved by the consensus of all authors. The search strategy and analysis were performed as per the Preferred Reporting Items for Systematic Review and Meta-Analysis (PRISMA) statement 2009 [13].

\section{Study selection}

Two investigators (VK and RJP) independently examined the abstracts of studies identified by the literature search. The following criteria were used for inclusion in the analysis: RCTs (blinded or unblinded) published between 1970 and 2015; trials comparing fenoldopam versus placebo for prevention of AKI; inclusion of patients undergoing major surgery (elective or emergency); and complete data available on any of the outcomes (Table 1). The exclusion criteria were: duplicate publications; studies not published in English; crossover studies; non-human experimental studies; or lack of complete or sufficient data to perform a meta-analysis of targeted outcomes. Two investigators (MAG and MO) then independently reviewed the full studies and assessed compliance with the pre-agreed selection criteria. Any disagreements were reviewed and resolved by a third author (PMH).

The Cochrane Collaboration Risk of Bias tool was used to assess the internal validity of included trials [14]. This tool consists of six domains (allocation concealment, random sequence generation, blinding, selective outcome reporting, incomplete outcome data, and other sources of bias). Each domain is rated low risk, unclear risk, or high risk. If one or more individual domains were considered as having a high risk of bias, the overall score was assessed as having a high risk of bias. The overall risk of bias was rated low only if all components were assessed as having a low risk of bias.

\section{Data extraction}

Two investigators (PMH and $\mathrm{MO}$ ) independently extracted the following information from each eligible article: study design (including patient selection and treatment allocation), population, clinical setting, dosage and duration of fenoldopam treatment, incidence of new AKI, requirement for RRT, hospital mortality and reported complications. If the necessary data could not be extracted from the publication, the original authors were contacted.

\section{Outcomes}

The primary outcome was incidence of new AKI (as defined by the author). Secondary outcomes were requirement for RRT and hospital mortality. If data on mortality was not reported, data on AKI or RRT were used; conversely, if only data on mortality were available then this was used. A priori, a decision was made to carry out a subgroup analysis on patients undergoing cardiac surgery.

\section{Statistical analysis}

Statistical analysis was performed using Review Manager (RevMan) v5.3, software used for preparing and maintaining Cochrane Reviews. Between-study statistical heterogeneity was assessed by $x^{2}$ test and $I^{2}$ test; values of the index of 25,50 , and $75 \%$ indicated the presence of low, moderate, and high between-trial heterogeneity, 
Table 1 Specification of the research question applying a PICO (population, intervention, comparison and outcome) model

\begin{tabular}{|c|c|c|c|}
\hline Population & Intervention & Comparison & Outcomes \\
\hline $\begin{array}{l}\text { Adult patients ( } \geq 18 \text { years) undergoing } \\
\text { any type of major surgery }\end{array}$ & $\begin{array}{l}\text { Treatment with fenoldopam in } \\
\text { the peri-operative period }\end{array}$ & Placebo & $\begin{array}{l}\text { Incidence of AKI Requirement for RRT } \\
\text { post-operatively Hospital mortality Side } \\
\text { effects (hypotension, need for } \\
\text { catecholamine treatment) }\end{array}$ \\
\hline
\end{tabular}

$A K I$ acute kidney injury, $R R T$ renal replacement therapy

respectively. A $p$-value of 0.1 was considered to indicate statistical significance of heterogeneity. The funnel plot method was used to estimate potential publication bias for any of the outcomes, either primary or secondary. Dichotomous outcomes were expressed as a difference of proportions (odds ratio (OR) with $95 \%$ confidence interval (CI)). If no significant heterogeneity was noted, the fixed-effect model (FEM) analysis using the Mantel-Haenszel method was performed. Otherwise, the Simonian-Laird method was used to present the results of the random-effects model (REM) analysis.

\section{Results}

Study selection

Figure 1 outlines the process for literature searching and study selection. Eighty-three non-duplicate publications were screened; 23 studies underwent full data extraction and scoring. Six trials were suitable for inclusion in the data synthesis (total of 507 subjects) (Table 2). Five trials were rated at high risk of bias (Table 3).

\section{Characteristics of included studies}

Three of the six included trials were performed in patients undergoing cardiac surgery [15-17]. The remaining three studies were undertaken in patients having aortic surgery [5], transplant surgery [18] or a partial nephrectomy [19] (Table 2). Funnel plot of studies used in the primary outcome analysis indicated no evidence of publication bias (Additional file 1).

\section{Primary outcome}

Data on post-operative incidence of new AKI were available in five of the six trials included in the analysis (total of 471 patients). In one study no patient developed AKI [5]. Significant reduction in AKI was observed in patients receiving fenoldopam (Fig. 2). Of 238 patients receiving fenoldopam, 45 (18.9\%) developed AKI compared to $62(26.6 \%)$ of 233 patients who received placebo $\left(p=0.004, I^{2}=0 \%\right.$; REM OR $0.46,95 \%$ CI $0.27-0.79$ ). Three of these studies $(\mathrm{n}=304)$ were performed in cardiac surgery patients [15-17]. When restricted to this cohort, significant reduction in author-defined AKI was also found between the group receiving fenoldopam and the control group $\left(p=0.003, I^{2}=0 \%\right.$; FEM OR $0.34,95 \%$ CI 0.16-0.69) (Additional file 2).

\section{Secondary outcomes}

Data on new requirement for RRT in the post-operative period were available in five of the six RCTs (total of 478 patients) [15-19]. Of 241 patients in the fenoldopam group, $2(0.8 \%)$ were treated with RRT post-operatively compared to $12(4.5 \%)$ of the 237 patients treated with placebo. The reduction in incidence of the need for RRT reported in the treatment arm was not significant $\left(p=0.11, I^{2}=47 \%\right.$; FEM OR $0.27,95 \%$ CI 0.06-1.19) (Additional file 3).

Hospital mortality data were included in only two of the six included RCTs, a total of 130 patients $[15,19]$. Of the 65 patients receiving fenoldopam, 2 (3.1\%) died compared to $2(3.1 \%)$ of 65 patients receiving placebo. There was no difference in hospital mortality between the fenoldopam and placebo group $\left(p=0.60, I^{2}=0 \%\right.$; FEM OR 1.0, 95 \% CI 0.14-7.37) (Fig. 3).

\section{Discussion}

The main finding of this analysis is that peri-operative administration of fenoldopam to patients undergoing cardiovascular surgery, partial nephrectomy or liver transplant surgery significantly reduced the development of AKI but did not significantly alter the requirement for RRT or hospital mortality. Whether the conclusions can be translated to other types of major surgery is unclear.

AKI is common in hospitalised patients, and influences both short- and long-term mortality. The recent multi-national Acute Kidney Injury - Epidemiologic Prospective Investigation (AKI-EPI) study demonstrated that AKI occurred in more than half of intensive care unit (ICU) patients (57 \%) [20]. Amongst patients admitted after surgery, $53 \%$ developed post-operative AKI. A study in patients undergoing cardiac surgery showed that those who developed AKI post-operatively had a significantly increased risk of dying for up to 10 years after surgery, even if renal function had recovered at the time of hospital discharge [21]. Similar data have also been reported for patients undergoing other major surgical procedures [22]. Hence, strategies to reduce or mitigate the incidence of peri-operative AKI are of high interest to clinicians.

The exact pathophysiology of AKI is not fully understood but includes haemodynamic factors, dysregulation of the renal microcirculation, inflammatory processes, mitochondrial dysfunction and bio-energetic disturbance, 


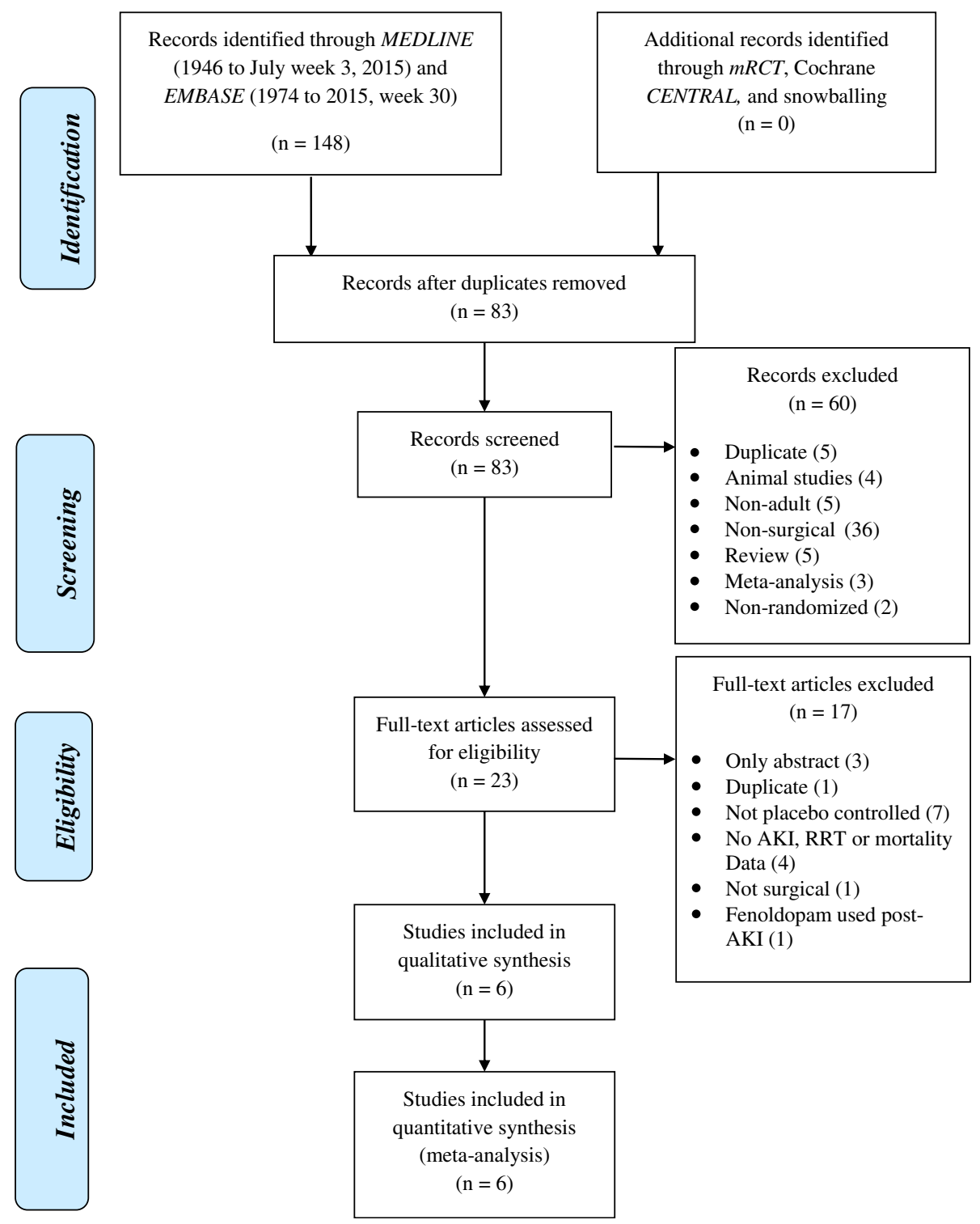

Fig. 1 PRISMA flow diagram detailing search strategy and identification of studies used in data synthesis. AKI acute kidney injury, RRT renal replacement therapy, $m R C T$ metaRegister of Controlled Trials

and exposure to toxic substances. Peri-operative hypoperfusion is an important risk factor for AKI following surgery, especially in combination with hypovolaemia [23]. It has been hypothesised that fenoldopam may be able to potentially reverse renal hypoperfusion, and hence prevent or resolve AKI. In addition, fenoldopam may also have anti-inflammatory effects independent of its vasodilatory action [7].

Landoni et al. conducted three separate meta-analyses exploring the role of fenoldopam [8-10]. The first metaanalysis focussed on the effect of fenoldopam in critically patients who had or were at risk of AKI [8]. Sixteen RCTs were included (total of 1290 patients). The analysis concluded that fenoldopam significantly reduced the development of AKI, need for RRT, length of stay (LOS) in ICU and hospital, and mortality. However, the analysis was limited by the inclusion of both surgical and nonsurgical critically ill patients (i.e. sepsis), only 10 of the included studies were placebo-controlled, most included studies were of low quality, and the indications for starting RRT were non-uniform between studies. Subsequently, they performed another meta-analysis with focus on studies in patients who underwent cardiovascular surgery [9]. They concluded that fenoldopam significantly reduced the need for RRT and was associated with a lower in-hospital mortality. Of note, of the 13 
Table 2 Summary of included studies

\begin{tabular}{|c|c|c|c|c|c|c|c|c|c|}
\hline Author & Time of study & Type of surgery & $\begin{array}{l}\text { Number of } \\
\text { patients (F/P) }\end{array}$ & Age (F/P) & $\begin{array}{l}\text { Dose and duration } \\
\text { of fenoldopam }\end{array}$ & $\begin{array}{l}\text { Inclusion of CKD } \\
\text { patients }\end{array}$ & Definition of AKI & $\begin{array}{l}\text { Reported } \\
\text { outcomes }\end{array}$ & $\begin{array}{l}\text { Reported side } \\
\text { effects }\end{array}$ \\
\hline O'Hara et al. [19] & $\begin{array}{l}\text { Nov } 2002 \text { to } \\
\text { April } 2010\end{array}$ & $\begin{array}{l}\text { Partial nephrectomy } \\
\text { in patients with } \\
\text { single kidney }\end{array}$ & $77(43 / 34)$ & $\begin{array}{l}59 / 59 \\
\text { (mean) }\end{array}$ & $\begin{array}{l}0.1 \mu \mathrm{g} / \mathrm{kg} / \mathrm{min} \text { for } \\
24 \mathrm{~h}\end{array}$ & Not reported & $\begin{array}{l}\text { RIFLE criteria or } \\
\text { change in GFR }\end{array}$ & $\begin{array}{l}\text { AKI RRT data } \\
\text { provided separately } \\
\text { by authors }\end{array}$ & None reported \\
\hline Ranucci et al. [17] & $\begin{array}{l}\text { Sept } 2008 \text { to } \\
\text { March } 2009\end{array}$ & $\begin{array}{l}\text { Elective cardiac } \\
\text { surgery with } \\
\text { expected CPB } \\
\text { time } \geq 90 \text { mins }\end{array}$ & $80(40 / 40)$ & $\begin{array}{l}65 / 64 \\
\text { (mean) }\end{array}$ & $\begin{array}{l}0.1 \mu \mathrm{gg} / \mathrm{kg} / \mathrm{min} \text { from } \\
\text { pre-operative to } \\
12 \mathrm{~h} \text { post-opertive }\end{array}$ & $\begin{array}{l}\text { Yes (including } 2 \\
\text { patients on } \\
\text { chronic dialysis) }\end{array}$ & $\begin{array}{l}\text { Peak } \mathrm{Cr}>2 \mathrm{mg} / \mathrm{dL} \\
\text { and } 100 \% \text { rise from } \\
\text { baseline for }>24 \mathrm{~h}\end{array}$ & $\begin{array}{l}\text { AKI 30-day } \\
\text { mortality }\end{array}$ & $\begin{array}{l}\text { Stroke, mechanical } \\
\text { ventilation, sternal } \\
\text { wound infection, } \\
\text { re-exploration }\end{array}$ \\
\hline Barr et al. [15] & $\begin{array}{l}\text { May } 2002 \text { to } \\
\text { Jan } 2006\end{array}$ & $\begin{array}{l}\text { Elective or } \\
\text { emergency cardiac } \\
\text { surgery in patients } \\
\text { with pre-operative } \\
\mathrm{CrCl} \leq 40 \mathrm{ml} / \mathrm{min}\end{array}$ & $38(19 / 19)$ & $\begin{array}{l}77.2 / 72.4 \\
\text { (mean) }\end{array}$ & $\begin{array}{l}0.1 \mu \mathrm{g} / \mathrm{kg} / \mathrm{min} \text { for } \\
48 \mathrm{~h}\end{array}$ & $\begin{array}{l}\text { Yes (CKD was } \\
\text { an inclusion } \\
\text { criterion) }\end{array}$ & $\begin{array}{l}\text { Difference in } \mathrm{CrCl} \text { as } \\
\text { per Cockcroft-Gault } \\
\text { formula between } \\
\text { pre-operative and } \\
\text { post-operative day } 3\end{array}$ & $\begin{array}{l}\mathrm{CrCl} \text { RRT Hospital } \\
\text { mortality }\end{array}$ & $\begin{array}{l}\text { Use of vasopressors } \\
\text { and inotropes }\end{array}$ \\
\hline Cogliati et al. [16] & Not reported & $\begin{array}{l}\text { High-risk cardiac } \\
\text { surgery }\end{array}$ & $193(95 / 98)$ & $\begin{array}{l}70.3 / 69.6 \\
\text { (mean) }\end{array}$ & $\begin{array}{l}0.1 \mathrm{\mu g} / \mathrm{kg} / \mathrm{min} \text { started } \\
\text { before surgical incision } \\
\text { until } 24 \mathrm{~h} \text { post-operative }\end{array}$ & Yes & $\begin{array}{l}\text { Serum } \mathrm{Cr} \text { rise to } \\
>2 \mathrm{mg} / \mathrm{dl} \text { with a rise } \\
\text { of } \geq 0.7 \mathrm{mg} / \mathrm{dl} \text { from } \\
\text { pre-operative to } \\
\text { post-operative }\end{array}$ & AKI RRT & None reported \\
\hline Biancofiore et al. [18] & $\begin{array}{l}\text { Jan } 2001 \text { to } \\
\text { July } 2003\end{array}$ & $\begin{array}{l}\text { Liver transplant } \\
\text { surgery }\end{array}$ & $92(46 / 46)$ & $\begin{array}{l}45 / 51 \\
\text { (median) }\end{array}$ & $\begin{array}{l}0.1 \mu \mathrm{g} / \mathrm{kg} / \mathrm{min} \text { from } \\
\text { induction until } 96 \mathrm{~h} \\
\text { post-operative }\end{array}$ & $\begin{array}{l}\text { Yes (provided } \\
\text { pre-operative } \\
\mathrm{Cr} \leq 1.5 \mathrm{mg} / \mathrm{dL} \text { ) }\end{array}$ & $\begin{array}{l}\text { Serum } \mathrm{Cr} \text { rise to } \\
>1.5 \mathrm{mg} / \mathrm{dl} \text { or } \\
\text { doubling of } \mathrm{Cr} \text { or } \\
\text { need for RRT }\end{array}$ & $\begin{array}{l}\text { AKI RRT Hospital } \\
\text { mortality }\end{array}$ & None reported \\
\hline Halpenny et al. [5] & Not reported & $\begin{array}{l}\text { Elective aortic } \\
\text { surgery with } \\
\text { infra-renal } \\
\text { cross-clamping }\end{array}$ & $27(14 / 13)$ & $\begin{array}{l}70 / 69 \\
\text { (mean) }\end{array}$ & $\begin{array}{l}0.1 \mu \mathrm{g} / \mathrm{kg} / \mathrm{min} \text { from } \\
\text { surgical incision until } \\
\text { release of aortic } \\
\text { cross-clamp }\end{array}$ & No & $\begin{array}{l}\text { Not specifically } \\
\text { defined }\end{array}$ & AKI & $\begin{array}{l}\text { Blood loss, MAP } \\
\text { and heart rate }\end{array}$ \\
\hline
\end{tabular}

Failure-Loss-End-stage renal disease, RRT renal replacement therapy 
Table 3 Quality summary: authors' assessment of risk of bias in randomised controlled trials included in meta-analysis

\begin{tabular}{|c|c|c|c|c|c|c|c|c|}
\hline Author & $\begin{array}{l}\text { Random sequence } \\
\text { generation }\end{array}$ & $\begin{array}{l}\text { Allocation } \\
\text { concealment }\end{array}$ & $\begin{array}{l}\text { Blinding of participants, personnel } \\
\text { and outcome assessors }\end{array}$ & $\begin{array}{l}\text { Incomplete outcome } \\
\text { data }\end{array}$ & $\begin{array}{l}\text { Selective outcome } \\
\text { reporting }\end{array}$ & $\begin{array}{l}\text { Commercial } \\
\text { involvement }\end{array}$ & $\begin{array}{l}\text { Other sources } \\
\text { of bias }\end{array}$ & $\begin{array}{l}\text { Overall } \\
\text { assessment }\end{array}$ \\
\hline O'Hara et al. [19] & Low risk & Low risk & Low risk & Low risk & Low risk & Low risk & Low risk & Low risk \\
\hline Ranucci et al. [17] & Low risk & Low risk & Low risk & Low risk & Low risk & Low risk & High risk ${ }^{a}$ & High risk \\
\hline Barr et al. [15] & Unclear & Low risk & Low risk & Low risk & Low risk & Low risk & Low risk ${ }^{\mathrm{a}}$ & High risk \\
\hline Cogliati et al. [16] & Low risk & Low risk & Low risk & Low risk & Low risk & Unclear & High risk ${ }^{a}$ & High risk \\
\hline Biancofiore et al. [18] & Low risk & Low risk & Low risk & Low risk & Low risk & Low risk & High risk ${ }^{a}$ & High risk \\
\hline Halpenny et al. [5] & Unclear & Unclear & Low risk & Low risk & Low risk & Unclear & High risk ${ }^{\mathrm{b}}$ & High risk \\
\hline
\end{tabular}

Risk of bias was judged by the authors to be high, unclear or low according to the Cochrane Collaboration's risk of bias assessment tool

${ }^{a} H i g h$ risk due to potential imbalance in number of patients with pre-existing chronic kidney disease

${ }^{\mathrm{b}}$ High risk because the definition of AKI was not provided 


\begin{tabular}{|c|c|c|c|c|c|c|c|c|c|c|}
\hline \multirow{2}{*}{$\begin{array}{l}\text { Study or Subgroup } \\
\text { Halpenny } 2001\end{array}$} & \multicolumn{2}{|c|}{ Fenoldopam } & \multicolumn{2}{|c|}{ Control } & Weight & \multirow{2}{*}{$\begin{array}{c}\text { Odds Ratio } \\
\text { M-H, Fixed, 95\% Cl } \\
\text { Not estimable }\end{array}$} & Year & \multicolumn{3}{|c|}{$\begin{array}{c}\text { Odds Ratio } \\
\text { M-H, Fixed, } 95 \% \mathrm{CI}\end{array}$} \\
\hline & 0 & 16 & 0 & 15 & & & 2001 & & & \\
\hline Cogliati 2003 & 12 & 95 & 27 & 98 & $55.1 \%$ & $0.38[0.18,0.81]$ & 2003 & $\square$ & & \\
\hline Biancofiore 2004 & 4 & 46 & 6 & 46 & $13.0 \%$ & $0.63[0.17,2.42]$ & 2004 & 8 & & \\
\hline Ranucci 2010 & 0 & 38 & 4 & 40 & $10.3 \%$ & $0.11[0.01,2.03]$ & 2010 & $\longleftarrow$ & & \\
\hline O'Hara 2013 & 29 & 43 & 25 & 34 & $21.6 \%$ & $0.75[0.28,2.01]$ & 2013 & $=$ & & \\
\hline Total $(95 \% \mathrm{Cl})$ & & 238 & & 233 & $100.0 \%$ & $0.46[0.27,0.79]$ & & & & \\
\hline Total events & 45 & & 62 & & & & & & & \\
\hline $\begin{array}{l}\text { Heterogeneity: } \mathrm{Chi}^{2}= \\
\text { Test for overall effect }\end{array}$ & $\begin{array}{l}2.32, d f= \\
Z=2.85\end{array}$ & $\begin{array}{l}=3(P= \\
(P=0 .\end{array}$ & $\begin{array}{l}=0.51) ; 1^{2} \\
004)\end{array}$ & $=0 \%$ & & & & 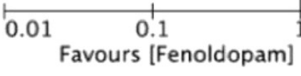 & Favours [control] & 100 \\
\hline
\end{tabular}

studies included in this meta-analysis, only nine were randomised, and of these only four were placebocontrolled. However, a post-hoc subgroup analysis of just the RCTs confirmed the beneficial effects of fenoldopam. Finally, the same authors completed a third meta-analysis where only placebo-controlled RCTs of fenoldopam in cardiac surgery patients were included [10]. Whilst there was a significant reduction in the development of AKI, fenoldopam did not have a statistically significant effect on RRT, or hospital and ICU LOS.

Landoni and colleagues also conducted a multi-centre, double-blind, placebo-controlled RCT to determine whether fenoldopam reduced the need for RRT in critically ill cardiac surgery patients with AKI [24]. There was no difference in RRT, ICU LOS, or mortality but a higher incidence of hypotension in patients receiving fenoldopam. While this is the largest study on the subject till date (667 patients overall), it had several limitations. The study was stopped early due to futility resulting in recruitment of only 667 patients instead of the planned 1000 patients. AKI was defined as per Risk-Injury-Failure-Loss-End-stage renal disease (RIFLE) classification but the criteria for initiating RRT were not pre-defined and left to the judgement of the treating clinicians.

To the best of our knowledge, our study is the only meta-analysis of fenoldopam use in the wider surgical population. Strengths of our study were that robust methodology was employed with an a priori analysis plan and only studies involving subjects undergoing surgery were included. All studies included were RCTs published in peer-reviewed journals. There was little statistical evidence of significant heterogeneity between studies; heterogeneity was absent in the primary outcome and in the secondary outcome of hospital mortality. Moderate heterogeneity was detected in the secondary outcome of new requirement for RRT.

However, in common with many meta-analyses, our study did have several potential sources of bias. The definition of AKI was not uniform between studies. In fact, all studies used different criteria for AKI as demonstrated in Table 2. Some investigators used very conservative criteria (e.g. peak creatinine $>2 \mathrm{mg} / \mathrm{dL}(196 \mu \mathrm{mol} / \mathrm{L}))$. None of the studies had pre-defined criteria for RRT. It is important to emphasize that our results have to be weighted on this limitation. It is certainly possible that different rates of AKI may have been observed if the authors had used current consensus criteria which define AKI by a rise in serum creatinine $>26.4 \mu \mathrm{mol} / \mathrm{L}$ in 48 hours or less, or a $50 \%$ rise in 7 days or less (according to the latest KDIGO consensus criteria) [12]. Furthermore, our results are based on studies that were performed in three specific types of surgery only, i.e. cardiovascular surgery, partial nephrectomy and liver transplant surgery. Whether the conclusions can be translated to other types of major surgery is unclear. It is also important to acknowledge that all included studies were underpowered. Only 473 patients were included in the meta-analysis for the primary outcome, and mortality data were only available for two studies (130 patients). Five of six studies included

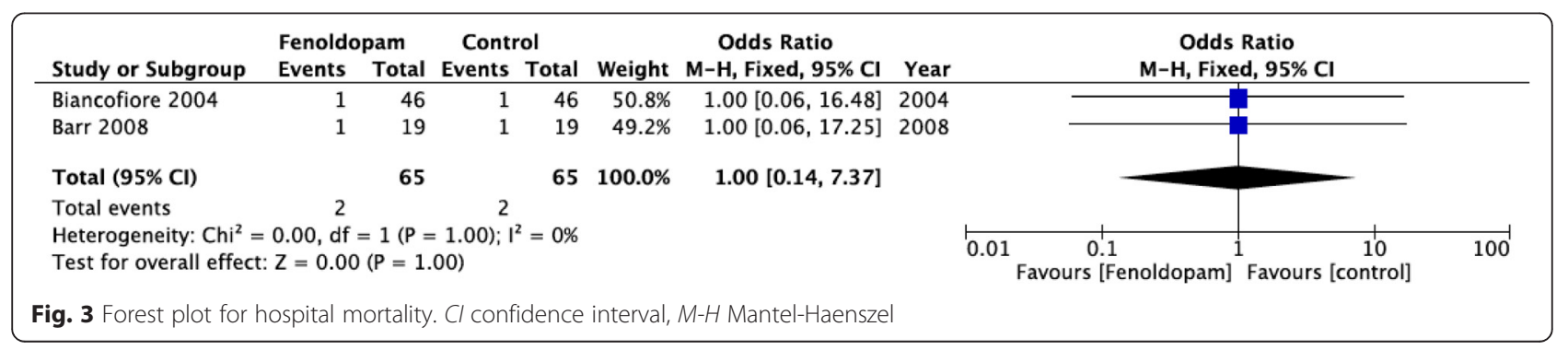


were deemed at high risk of bias using the Cochrane Assessment Tool [14]. The main reasons for this were a potential imbalance in the number of patients with pre-existing CKD. Finally, if fenoldopam does indeed have a beneficial effect on renal function during the peri-operative period, the optimal duration of therapy is unknown. In all studies, fenoldopam was administered at $0.1 \mu \mathrm{g} / \mathrm{kg} / \mathrm{min}$, but the duration of therapy varied from the end of surgery to 96 hours postoperatively.

In summary, there may be a role for fenoldopam in preventing AKI following high-risk surgery; however, identification of the patients most likely to benefit and the optimal dose and duration of therapy remains yet to be defined. Future well-powered studies should compare fenoldopam with placebo in a much wider patient group with normal renal function undergoing high-risk surgery. Moreover the definitions of AKI, and the indications for RRT, should also be pre-defined and be consistent with current consensus criteria.

\section{Conclusions}

This meta-analysis suggests that peri-operative fenoldopam administration in surgical patients was associated with a reduction in AKI but there was no effect on RRT or mortality. Non-standard classification of AKI in the majority of studies included in this analysis means that these results should be interpreted with great caution. Equipoise remains for further adequately powered trials of fenoldopam in the high-risk surgical population; however, optimum dose and duration of therapy have yet to be defined.

\section{Key messages}

- Meta-analysis of six randomised controlled trials showed that peri-operative treatment with fenoldopam was associated with a significant reduction in acute kidney injury after major surgery.

- Peri-operative treatment with fenoldopam had no impact on requirement for renal replacement therapy or hospital mortality.

- Further research is required to determine the role of fenoldopam since the studies only included cardiovascular surgery, partial nephrectomy and liver transplant surgery, the majority of studies were at high risk of bias and the criteria for acute kidney injury varied between studies.

\section{Additional files}

Additional file 1: Funnel plot for primary outcome (author defined acute kidney injury). (DOC $55 \mathrm{~kb}$ )
Additional file 2: Forrest plot of acute kidney injury for cardiac surgery subgroup. (DOC $58 \mathrm{~kb}$ )

Additional file 3: Forest plot of new requirement for renal replacement therapy. (DOC $68 \mathrm{~kb}$ )

\section{Abbreviations}

AKI: Acute kidney injury; Cl: Confidence interval; CKD: Chronic kidney disease; FEM: Fixed-effect model; ICU: Intensive care unit; KDIGO: Kidney Disease Improving Global Outcomes; LOS: Length of stay; OR: Odds ratio; PRISMA: Preferred Reporting Items for Systematic Review and Meta-Analysis: RCT: Randomised controlled trial; REM: Random-effects model; RIFLE: Risk-Injury-Failure-Loss-End-stage renal disease; RRT: Renal replacement therapy.

\section{Competing interests}

PMH has received research grants from Gambro, Baxter, Astute, Pfizer and Bellco. MO has received speaker honoraria from Fresenius and Gambro. All other authors declare that they have no competing interests.

\section{Authors' contributions}

All authors contributed equally to the design and conduct of the study and preparation of the manuscript. MO and MAG take responsibility for the conduct of the study and the integrity of the results. All authors approved the final manuscript.

\section{Acknowledgements}

The study group would like to thank Dr. Mark Hamilton for his advice in preparing the study protocol and conducting the analysis.

\section{Author details}

'Department of Anaesthesia, Critical Care \& Pain Medicine, Royal Infirmary of Edinburgh, Edinburgh, UK. ${ }^{2}$ Department of Critical Care, King's College Hospital NHS Foundation Hospital, London, UK. ${ }^{3}$ Aintree University Hospital NHS Foundation Hospital, Department of Critical Care Medicine, Liverpool, UK. ${ }^{4}$ Department of ICU, Universitair Ziekenhuis Brussel, Vrije Universiteit Brussel (VUB University), Brussels, Belgium. ${ }^{5}$ Department of Nephrology \& Critical Care Medicine, King's College London, Guy's \& St Thomas' Foundation Hospital, London, UK.

Received: 3 November 2015 Accepted: 10 December 2015

Published online: 25 December 2015

\section{References}

1. Carmichael P, Carmichael AR. Acute renal failure in the surgical setting. ANZ J Surg. 2003;73:144-53.

2. Kheterpal S, Tremper KK, Englesbe MJ, O'Reilly M, Shanks AM, Fetterman DM, et al. Predictors of postoperative acute renal failure after non-cardiac surgery in patients with previously normal renal function. Anesthesiology. 2007;107:892-902

3. Chertow GM, Burdick E, Honour M, Bonventre JV, Bates DW. Acute kidney injury, mortality, length of stay, and costs in hospitalized patients. J Am Soc Nephrol. 2005;16:3365-70.

4. Nichols AJ, Ruffolo Jr RR, Brooks DP. The pharmacology of fenoldopam. Am J Hypertens. 1990;3:116S-9S.

5. Halpenny M, Rushe C, Breen P, Cunningham AJ, Boucher-Hayes D, Shorten GD. The effects of fenoldopam on renal function in patients undergoing elective aortic surgery. Eur J Anesthesiol. 2002;19:32-9

6. Caimmi PP, Pagani L, Micalizzi E, Fiume C, Guani S, Bernardi M, et al. Fenoldopam for renal protection in patients undergoing cardiopulmonary bypass. J Cardiothorac Vasc Anesth. 2003;17:491-4.

7. Aravindan N, Natarajan M, Shaw AD. Fenoldopam inhibits nuclear translocation of nuclear factor kappa B in a rat model of surgical ischaemic acute renal failure. J Cardiothorac Vasc Anesth. 2006;20:179-86.

8. Landoni G, Biondi-Zoccai GG, Tumlin JA, Bove T, De Luca M, Calabrò MG, et al. Beneficial impact of fenoldopam in critically ill patients with or at risk of acute renal failure: a meta-analysis of randomised clinical trials. Am J Kidney Dis. 2007;49(1):56-68. 
9. Landoni G, Biondi-Zoccai GG, Marino G, Bove T, Fochi O, Maj G, et al. Fenoldopam reduces the need for renal replacement therapy and inhospital death in cardiovascular surgery: a meta-analysis. J Cardiothorac Vasc Anesth. 2008:22(1):27-33.

10. Zangrillo A, Biondi-Zoccai GG, Frati E, Covello RD, Cabrini L, Guarracino F, et al. Fenoldopam and acute renal failure in cardiac surgery: a meta-analysis of randomized placebo-controlled trials. J Cardiothorac Vasc Anesth. 2012;26(3):407-13.

11. Joannidis M, Druml W, Forni LG, Groeneveld AB, Honore P, Oudemans-van Straaten $\mathrm{HM}$, et al. Prevention of acute kidney injury and protection of renal function in the intensive care unit-expert opinion of the working group of nephrology. ESICM Intensive Care Med. 2010;26:392-411.

12. Kidney Disease Improving Global Outcomes (KDIGO) Acute Kidney Injury Work Group. KDIGO clinical practice guideline for acute kidney injury. Kidney Int (Suppl). 2012;1-138.

13. Moher D, Liberati A, Tetzlaff J, The ADG, PRISMA Group. Preferred reporting items for systematic reviews and meta-analyses: The PRISMA statement. PLoS Med. 2009;6(7):e1000097.

14. Higgins JP, Altman DG, Gotzsche PC, Jüni P, Moher D, Oxman AD, et al. The Cochrane Collaboration's tool for assessing risk of bias in randomised trials. BMJ. 2011;343:d5928.

15. Barr LF, Kolodner K. N-acetylcysteine and fenoldopam protect the renal function of patients with chronic renal insufficiency undergoing cardiac surgery. Crit Care Med. 2008:36:1427-35.

16. Cogliati AA, Vellutini R, Nardini A, Urovi S, Hamdan M, Landoni G, et al. Fenoldopam infusion for renal protection in high-risk cardiac surgery patients: a randomized clinical study. J Cardiothorac Vasc Anesth. 2007;21(6): 847-50.

17. Ranucci M, De Benedetti D, Bianchini C, Castelvecchio S, Ballotta A, Frigiola A, et al. Effects of fenoldopam infusion in complex cardiac surgical operations: a prospective, randomized, double-blind, placebo-controlled study. Minerva Anestesiol. 2010;76(4):249-59.

18. Biancofiore G, Della Rocca G, Bindi L, Romanelli A, Esposito M, Meacci L, et al. Use of fenoldopam to control renal dysfunction early after liver transplantation. Liver Transpl. 2004;10:986-92.

19. O'Hara JF, Mahboobi R, Novak SM, Bonilla AM, Mascha EJ, Fergany AF, et al. Fenoldopam and renal function after partial nephrectomy in a solitary kidney: a randomized, blinded trial. Urology. 2013;81:340-6.

20. Hoste E, Bagshaw SM, Bellomo R, Cely CM, Colman R, Cruz DN, et al. Epidemiology of acute kidney injury in critically ill patients: the multinational AKI-EPI study. Intensive Care Med. 2015:41:1411-23.

21. Hobson CE, Yavas S, Segal MS, Schold JD, Tribble CG, Layon AJ, et al. Acute kidney injury is associated with increased long-term mortality after cardiothoracic surgery. Circulation. 2009:119:2444-53.

22. Bihorac A, Yavas S, Subbiah S, Hobson CE, Schold JD, Gabrielli A, et al. Long-term risk of mortality and acute kidney injury during hospitalization after major surgery. Ann Surg. 2009;249(5):851-8.

23. Tang IY, Murray PT. Prevention of perioperative acute renal failure: what works? Best Pract Res Clin Anesthesiol. 2004;18:91-111.

24. Bove T, Zangrillo A, Guarracino F, Alvaro G, Persi B, Maglioni E, et al. Effect of Fenoldopam on use of renal replacement therapy among patients with acute kidney injury after cardiac surgery: A randomized clinical trial. JAMA. 2014;312(21):2244-53.

\section{Submit your next manuscript to BioMed Centra and we will help you at every step:}

- We accept pre-submission inquiries

- Our selector tool helps you to find the most relevant journal

- We provide round the clock customer support

- Convenient online submission

- Thorough peer review

- Inclusion in PubMed and all major indexing services

- Maximum visibility for your research

Submit your manuscript at www.biomedcentral.com/submit

) Biomed Central 